\title{
Pengaruh Modal dan Tenaga Kerja terhadap Pendapatan UMKM Kerupuk Ikan SPN Kota Jambi
}

\author{
Habriyanto*, Bambang Kurniawan, David Firmansyah \\ Fakultas Ekonomi dan Bisnis Islam, Universitas Islam Negeri Sulthan Thaha Saifuddin Jambi \\ *Correspondence email: habriyanto@uinjambi.ac.id, habriyanto781@gmail.com, bambangkurniawan@uinjambi.ac.id
}

\begin{abstract}
Abstrak. Penelitian ini bertujuan untuk mengetahui pengaruh modal kerja dan tenaga kerja terhadap pendapatan UMKM kerupuk ikan SPN kota jambi secara deskriptif kuantitatif mengenai: Bagaimana pengaruh modal kerja dan tenaga kerja terhadap pendapatan umkm kerupuk ikan spn kota jambi. Penelitian ini diharapkan dapat memberikan manfaat kepada penulis, instansi, dan akademisi terkait dengan pendapatan kerupuk ikan SPN, serta mejadi sumber informasi bagi pemilik usaha kerupuk ikan SPN untuk dapat mengoptimalkan pendapatannya. Jenis penelitian ini adalah kuantitatif-deskriptif, karena penelitian ini mengakomodasi bentuk angka-angka dan pengolahan data menggunakan analisis regresi linear berganda dengan bantuan aplikasi IBM statistics 22. Adapun data yang digunakan adalah data sekunder berupa data time series dari tahun 2018 hingga tahun 2020 yang di peroleh dari pemilik usaha kerupuk ikan SPN. Berdasarkan hasil penelitian yang telah dilakukan, diperoleh data dari variabel modal kerja dan tenaga kerja berpengaruh positif dan signifikan terhadap pendapatan. Berdasarkan pengujian menggunakan analisis komponen utama menunjukan variabel modal kerja memiliki nilai siginifikan $(0.00<0,05)$ dengan nilai koefisien sebesar 0.724. , variabel tenaga kerja mempunyai nilai siginifikan $(0.755<0,05)$ dengan nilai koefisien .042 .
\end{abstract}

Kata kunci: Modal Kerja; Tenaga Kerja; Pendapatan

Abstract. This study aims to determine the effect of working capital and labor on the income of MSME fish cracker SPN Jambi City in a quantitative descriptive of: How are the effects of working capital and labor on the income of fish cracker fish in Jambi City. This research is expected to provide benefits to authors, agencies, and academics related to SPN fish cracker income, as well as a source of information for SPN fish cracker business owners in order to optimize their income. This type of research is quantitative-descriptive, because this research accommodates the form of numbers and data processing using multiple linear regression analysis with the help of the IBM statistics 22 application. The data used is secondary data in the form of time series data from 2018 to 2020 which is obtained from the SPN fish cracker business owner. Based on the results of research that has been done, data obtained from the variables of working capital and labor have a positive and significant effect on income. Based on the test using main component analysis, it shows that the working capital variable has a significant value $(0.00<0.05)$ with a coefficient value of 0.724 . , the labor variable has a significant value $(0.755<0.05)$ with a coefficient value of .042 .

Keywords: Working Capital; Labor; and Income

\section{PENDAHULUAN}

UMKM atau usaha mikro kecil menengah yang terus berkembang merupakan kekuatan ekonomi yang dimiliki suatu negara. Selain sebagai kekuatan ekonomi, usaha mikro kecil menengah atau UMKM juga merupakan basis bagi kekokohan struktur ekonomi. Hal ini dikarenakan UMKM menjual produk relatif lebih murah serta item-item produk yang diproduksi oleh usaha besar di lakukan atau dikerjakan oleh pelaku UMKM itu sendiri. Beberapa hal tersebut yang membuat berbagai pihak sadar akan pentingnya UMKM sebagai salah satu pengokoh perekonomian dalam negeri. (Suryana, 2011)

Dari berbagai sektor, dalam perekonomian dalam negeri saat ini UMKM memiliki kedudukan sebagai pemeran utama dalam aktivitas ekonomi. Dalam Undang-undang No. 20 tahun 2008, UMKM merupakan usaha produktif milik orang peorangan atau badan usaha perorangan yang memenuhi kriteria usaha mikro. UMKM diharapkan dapat menjadi pelaku utama yang produktif dan berdaya saing dalam perekonomian nasional. (Kementerian Hukum dan HAM, 2008)
Demi mewujudkan perekonomian yang produktif dan dapat bersaing dalam perekonomian nasional maka kita perlu memperhatikan potensi-potensi usaha mikro dan kecil menengah (UMKM) yang ada di setiap provinsi Indonesia, salah satu potensi usaha mikro dan kecil menengah yang baik yaitu di provinsi jambi. Banyaknya jumlah penduduk serta tingginya kreativitas warga ini menjadikan kota jambi sebagai tempat yang baik untuk membuka bisnis.

Menurut badan pusat statistik pada tahun 2020 hingga saat ini terdapat 104.155 UMKM di Provinsi Jambi yang tersebar di sebelas kabupaten dan kota. Terdiri dari pelaku usaha mikro sebanyak 90.845 usaha, usaha kecil sebanyak 12.402 dan usaha menengah sebanyak 908, banyaknya UMKM pada saat ini, hal tersebut berpengaruh pada penyerapan tenaga kerja yang ada. (BPS Propinsi Jambi, 2020)

Usaha mikro kecil menengah telah banyak berperan dalam rangka penyerapan tenaga kerja bagi warga sekitarnya dan memberi kesempatan berusaha, serta mampu untuk meningkatkan pendapatan bagi pengusaha industri dalam memenuhi berbagai kebutuhan 
hidupnya. Pendapatan merupakan jumlah uang yang diterima oleh perusahaan dari aktivitasnya, kebanyakan dari penjualan produk atau jasa kepada pelanggan. Dalam mencapai tujuan dari perusahan untuk mendapatkan pendapatan yang tinggi maka perlu adanya pengelolaan sebuah perusahaan yaitu dengan adanya perencanaan yang matang dan strategi yang baik. (Melinda, 2020)

Meningkatnya pendapatan merupakan salah satu faktor yang sangat penting dalam memenuhi kebutuhan modal kerja. Maka dari itu perusahaan memerlukan sumber pembiayaan atau dana dengan adanya peningkatan pendapatan tersebut. Sehingga dengan adanya peningkatan penjualan maka profitabilitas perusahaan meningkat pula. Karena salah satu yang mempengaruhi profitabilitas adalah kegiatan pendapatan dimana barang yang sudah diproduksi oleh perusahaan sudah siap untuk dipasarkan dan digunakan oleh konsumen. (Kemang Widya, 2018).

Pengelolaan modal kerja yang baik sangat penting agar kelangsungan usaha pada suatu perusahaan dapat dipertahankan sehingga tidak mengalami kebangkrutan. Karena modal kerja merupakan modal yang harus dikeluarkan untuk membeli atau membuat barang dagangan. Modal kerja ini bisa dikeluarkan setiap bulan, atau setiap datang pesanan (order). Pada prinsipnya tanpa modal kerja, pesanan (order) tidak dapat terselesaikan atau tidak ada barang dagang yang diperdagangkan. Setelah barang selesai diproduksi, maka barang tersebut akan dijual, dari hasil penjualan tersebut pemilik usaha akan mendapatkan pendapatan. (Anindita Trinura Novitasari, 2017)

Selain modal kerja, tenaga kerja juga merupakan faktor yang sangat penting dalam produksi, karena tenaga kerja merupakan faktor penggerak serta faktor input yang lain, tanpa adanya tenaga kerja maka faktor produksi lain tidak akan berarti. Dengan meningkatnya produktifitas tenaga kerja akan mendorong peningkatan produksi sehingga pendapatan pun akan ikut meningkat. Apabila banyak produk yang terjual dengan demikian pengusaha akan meningkatkan jumlah produksinya. Meningkatnya jumlah produksi akan mengakibatkan meningkatnya tenaga kerja yang dibutuhkan, sehingga dengan demikian pedapatan juga akan meningkat. (Sonny Sumarsono, 2013)

Maka dari itu tenaga kerja merupakan hal penting yang harus ada di dalam kegiatan suatu industri karena tenaga kerja adalah orang yang mampu melakukan pekerjaan guna menghasilkan barang dan/atau jasa baik untuk memenuhi kebutuhan sendiri maupun untuk masyarakat. (Dwi Nila Andriani, 2017)

Dari pembahasan diatas peneliti mencoba untuk meneliti perusahaan kerupuk ikan SPN kota jambi, dimana usaha kerupuk tersebut terus mengalami penurunan pendapatan. Penurunan pendapatan tersebut terjadi karena penurunan faktor produksi yaitu seperti modal kerja dan tenaga kerja. Data penurunan factor produksi tersebut berdasarkan hasil dokumentasi dan wawancara dari pemilik kerupuk ikan SPN kota jambi:

"Masalah yang sering dihadapi yaitu modal kerja dan sumber daya manusia, dimana pelaku usaha kekurangan modal kerja dalam proses produksi, Usaha ini merupakan milik pribadi dan tidak ada peran siapapun, apabila kekukarangan modal kerja maka akan meminjam ke koperasi karena urusan yang lebih mudah. Yang kedua tenaga kerja, tenaga kerja yang dimiliki hanya sedikit, sehingga kesulitan dalam mendistribusikan produk, seperti contoh kurang nya tenaga kerja yang mengantar produk ke toko-toko sehingga jangkauan pemasaran produk hanya sedikit, kemudian tenaga kerja yang digunakan berasal dari keluarga sendiri". (Wawancara, 2 Februari 2021)

Tabel 1. Data Modal Kerja, Tenaga Kerja, dan Pendapatan Kerupuk Ikan SPN Kota Jambi Periode 2018-2020

\begin{tabular}{ccccc}
\hline Tahun & Modal Kerja & Tenaga Kerja & Pendapatan & Persentase (\%) \\
\hline $\mathbf{2 0 1 8}$ & 48.950 .000 & 3 & 76.380 .000 & $-21 \%$ \\
$\mathbf{2 0 1 9}$ & 40.650 .000 & 2 & 62.210 .000 & $-18 \%$ \\
$\mathbf{2 0 2 0}$ & 21.300 .000 & 2 & 33.090 .000 & $-46 \%$ \\
\hline
\end{tabular}

Sumber Data: Pemilik Kerupuk Ikan SPN

Pada tabel diatas, terdapat tiga data yaitu data modal kerja, tenaga kerja dan pendapatan. Pada tabel pertama yaitu data tentang modal kerja dari tahun 2018 sampai dengan tahun 2020, pada tabel kedua yaitu data tenaga kerja, kemuidan berikutnya data pendapatan UMKM kerupuk ikan SPN dari tahun 2018 sampai tahun 2020.

Pada tahun 2018 modal kerja yang dimiliki UMKM kerupuk SPN ini sebesar Rp.48.950.000, modal kerja ini memilik selisihi yang tidak begitu jauh dengan modal kerja sebelumnya, tenaga kerja yang dimilik yakni 3 orang, dengan berkurangnya modal kerja yang dikeluarkan hal ini berdampak pada pendapatan pada tahun ini menurun $-21 \%$ atau sebesar $\mathrm{Rp} 76.380 .000$.

Pada tahun berikutnnya yaitu tahun 2019 modal kerja usaha ini menurun kembali sebesar Rp. 8.300.000 yakni sebesar Rp. 40.650 .000 pada tahun ini tenaga kerja usaha kerupuk ikan ini berkurang menjadi 2 orang, dengan berkurangnya modal kerja dan tenaga kerja pada tahun ini pendapatan usaha kerupuk ini mengalami penurunan pendapatan $-18 \%$ atau sebesar Rp. 62.210.000. Pada tahun 2020, tahun ini merupakan tahun dimana pendapatan menurun drastis yakni sebesar $-46 \%$ pada 2019 pendapatan Rp 62.210.000, menurun $-46 \%$ sebesar Rp 33.090.000.

Dari penjelasan diatas dapat disimpulkan bahwa pendapatan yang dihasilkan setiap tahun nya mengalami penurunan, apabila penurunan tersebut terus terjadi maka di khawatirkan bagi kelangsungan usaha tersebut. maka dari itu perlu adanya tindakan dari pemilik usaha tersebut, hal itu adalah dengan menambah pengeluaran 
modal kerja serta tenaga kerja. Setiap bertambahnya modal kerja dan tenaga kerja yang dikeluarkan akan berdampak pada kenaikan pendapatan yang dihasilkan. Begitu pula sebaliknya dengan berkurang modal kerja yang dikeluarkan dan tenaga kerja yang dimiliki maka pendapatan usaha ini juga ikut berkurang. Selain data diatas hal ini juga dibuktikan dengan penelitian terdahulu yang dimana menurut Fitria anggraeni puspita sari, modal kerja berpengarih positif dan signifikan terhadap pendapatan. (Fitria Angreani, 2020)

Dari permasalahan di atas dapat di lihat bahwa modal kerja dan tenaga kerja sangat berpengaruh terhadap pendapatan. Hal ini dikarenakan modal kerja merupakan faktor penting yang sangat diperlukan demi keberlangsungan usaha, begitu pula tenaga kerja. Tenaga kerja sangat berpengaruh terhadap peningkatan produksi industri dan memperlancar pemasaran produk.

\section{Tinjauan Teoritis \\ Pengertian Modal}

Menurut James C Van Harne dalam Nase Saipudin Zuhri, (2017), menyatakan bahwa modal kerja bersih adalah adalah aktiva lancar dikurangi kewajiban lancar, dan modal kerja kotor adalah investasi perusahaan dalam aktiva lancar seperti kas, piutang dan persediaan. Modal kerja merupakan modal yang dibutuhkan untuk jalannya operasional usaha, baik yang digunakan biaya pengeluaran tetap setiap bulannya maupun biaya pengeluaran yang tidak tetap setiap bulannya.

Dalam pandangan Al- Quran, uang merupakan modal serta salah satu faktor produksi yang penting, tetapi "bukan yang terpenting". Manusia menduduki tempat modal disusul sumber daya alam. Pandangan ini berbeda dengan pandangan sementara pelaku ekonomi modern yang memandang uang sebagai segala sesuatu, sehingga tidak jarang manusia atau sumber daya alam dianiaya atau ditelantarkan. (Rahmat Syafei, 2001)

Dalam sistem ekonomi Islam modal kerja diharuskan terus berkembang agar sirkulasi uang tidak terhenti. Dikarenakan jika modal kerja atau uang terhenti (ditimbun) maka harta itu tidak dapat mendatangkan manfaat bagi orang lain, termasuk diantaranya jika ada bisnis berjalan maka akan bisa menyerap tenaga kerja. Islam melarang penimbunan harta dan sebaliknya mendorong sirkulasi harta di antara semua bagian masyarakat.

Modal kerja digolongkan dalam beberapa jenis, yaitu:

1. Modal Kerja Permanen (Permanent Working Capital) Yaitu modal kerja yang ada pada perusahaan untuk dapat menjalankan fungsinya antara modal kerja ini terdiri dari:

a. Modal kerja primer (Primary Working Capital) jumlah modal kerja minimum yang harus ada pada perusahaan untuk menjaga kontinuitas usahanya. b. Modal kerja normal (Normal Working Capital) modal kerja yang dibutuhkan untuk menyelenggarakan proses produksi yang normal.

2. Modal Kerja Variabel (Variable Working Capital)

Yaitu modal kerja yang jumlahnya berubah-ubah sesuai dengan perubahan keadaan. Modal kerja ini dibagi:

a. Modal kerja musiman (Seasond Working Capital) modal kerja yang jumlahnya berubah-rubah disebabkan oleh fluktuasi musim.

b. Modal kerja siklis (Cyclical Working Capital) modal kerja yang jumlahnya berubah-rubah disebabkan oleh fluktuasi kongjuntur.

c. Modal kerja darurat (Emergency Working Capital) modal kerja yang jumlahnya berubah-rubah karena keadaan darurat yang tidak diketahui sebelumnya. (Nase Saipudin Zuhri, 2017)

\section{Faktor-Faktor Yang Mempengaruhi Modal Kerja}

Menurut Hampton perusahaan membutuhkan modal kerja ditentukan oleh 4 faktor:

1. Volume Penjualan

2. Perusahaan membutuhkan modal kerja untuk mendukung kegiatan operasional pada saat terjadi peningkatan penjualan.

3. Faktor Musim dan Siklus

Fluktuasi dalam penjualan yang disebabkan oleh faktor musim dan siklus akan mempengaruhi kebutuhan akan modal kerja.

4. Perubahan Dalam Teknologi

Jika perubahan pengembangan teknologi maka akan berhubungan dengan proses produksi dan akan membawa dampak terhadap kebutuhan akan modal kerja.

5. Kebijakan Perusahaan

Kebijakan yang diterapkan oleh perusahaan juga akan membawa dampak terhadap kebutuhan modal kerja (Nase Saipudin Zuhri, 2017)

\section{Tenaga Kerja}

Tenaga kerja adalah semua yang bersedia dan sanggup bekerja. Golongan ini meliputi yang bekerja untuk kepentingan sendiri, baik anggota-anggota keluarga yang tidak menerima bayaran berupa uang maupun mereka yang bekerja untuk gaji dan upah. Juga yang menganggur, tetapi yang sebenarnya bersedia dan mampu untuk bekerja. (Mahardika, 2018)

Dalam Islam, setiap orang dituntut untuk bekerja sesuai dengan kemampuannya sehingga ia mampu mencukupi kebutuhan diri dan keluarga. Namun, kenyataannya ada di antara anggota masyarakat tidak mampu bekerja sehingga mereka tidak berpenghasilan. Ada juga anggota masyarakat yang mampu bekerja, tetapi tidak mendapatkan pekerjaan (pengangguran) ataupun mendapatkan pekerjaan, tetapi memperoleh 
penghasilan yang memadai karena banyaknya anggota keluarga. (Rozalinda, 2014)

Bekerja atau berusaha merupakan senjata utama untuk memerangi kemiskinan. Bekerja merupakan cara memperoleh penghasilan, laba ataupun imbalan yang dapat dipergunakan untuk memenuhi kebutuhan diri dan keluarga. Hal ini akan terwujud apabila sistem islam yang mengatur kehidupan sosial, politik, dan ekonomi dilaksanakan secara konsisten. (Rozalinda, 2014)

\section{Klasifikasi Tenaga Kerja}

Tenaga kerja manusia menurut tingkatannya (kualitasnya) yang terbagi atas:

1. Tenaga kerja terdidik (skilled labour), adalah tenaga kerja yang memperoleh pendidikan baik formal maupun non formal, seperti guru, dokter, pengacara, akuntan, psikologi, peneliti.

2. Tenaga kerja terlatih (trained labour), adalah tenaga kerja yang memperoleh keahlian berdasarkan latihan dan pengalaman. Misalnya, montir, tukang kayu, tukang ukir, sopir, teknisi.

3. Tenaga kerja tak terdidik dan tak terlatih (unskilled and untrained labour), adalah tenaga kerja yang mengandalkan kekuatan jasmani dari pada rohani, seperti tenaga kuli panggul, tukang sapu, pemulung,buruh tani.(Arininoer Maliha, 2018)

\section{Jenis-Jenis Tenaga Kerja}

Faktor produksi berupa tenaga kerja ini adalah manusia/SDM yang mempunyai keahlian dan keterampilan yang dibedakan 3 golongan, yaitu:

1. Tenaga kerja kasar.

Tenaga kerja tidak berpendidikan atau berpendidikan rendah dan tidak memiliki keahlian dalam suatu bidang pekerjaan (contoh: tukang jalan sapu, kuli bangunan dan lain-lain)

2. Tenaga kerja terampil

Tenaga kerja yang memiliki keahlian dari pelatihan atau pengalaman kerja (contoh: montir mobil, tukang bayu, perbaikan TV dan lain-lain.)

3. Tenaga terdidik.

Tenaga kerja yang memiliki Pendidikan cukup tinggi dan ahli dalam bidang tertentu (contoh: dokter, akuntan, insinyur dan lain-lain). (Mahardika, 2018)

\section{Pengertian Pendapatan}

Pendapatan adalah jumlah penghasilan yang diterima oleh penduduk atas prestasi kerjanya selama satu periode tertentu, baik harian, mingguan, bulanan ataupun tahunan. Pendapatan merupakan hasil dari suatau usaha seperti home industri yang sedang beroperasi. Hal itu biasanya di ukur dalam satuan harga pertukaran yang berlaku. Pendapatan diakui setelah kejadian penting atau setelah terjadinya proses penjualan pada dasarnya telah diselesaikan. Dalam praktek ini biasanya pendapatan diakui pada saat terjadinya penjualan. (Meta Trisnawati, 2013)

Pendapatan seseorang merupakan pendapatan yang secara langsung diterima yang berasal dari berbagai sumber. Pendapatan dapat diterima dalam berbagai kegiatan produksi yang merupakan hasil dari balas jasa dalam jangka waktu tertentu. Balas jasa yang diterima dapat berupa gaji atau upah, sewa, laba ataupun bunga. (Putu Denandra Putra, 2015)

Menurut Sumarso, (2003) pendapatan dalam perusahaan dapat diklasifikasikan sebagai pendapatan operasi dan pendapatan non operasi.

1. Pendapatan operasi adalah pendapatan yang di peroleh dari aktivitas utama perusahaan. Pendapatan operasi dapat di peroleh dari dua sumber yaitu:

a. Penjualan kotor adalah penjualan sebagaimana tercantum dalam faktur atau jumlah awal pembebanan sebelum dukurangi penjualan return dan potongan penjualan.

b. Penjualan bersih adalah penjualan yang diperoleh dari penjualan kotor dikurangi return penjualan ditambah dengan potongan penjualan dan lainlain.

2. Pendapatan non operasi adalah pendapatan yang bukan dari kegiatan utama perusahaan. (Sumarso, 2003)

Pendapatan yang diperoleh dari penggunaan aktiva atau sumber ekonomi perusahaan atau pihak lain, contohnya: pendapatan bunga dan sewa.

Jadi berdasarkan sistem perekonomian sederhana jenis pendapatan dapat dibagi menjadi sektor rumah tangga dan perusahaan. Dalam rumah tangga pendapatan dibagi menjadi 3 jenis yaitu: pendapatan formal, informal, dan sup sistem, sedangkan pendapatan perusahaan dibagi menajadi 2 jenis yaitu: pendapatan operasional dan pendapatan non operasional. Adapun jenis pendapatan yang dimaksud dalam penelitian ini adalah berupa pendapatan formal, informal, dan sup sistem berupa uang yang diterima atas penjualan barang dagang atau produk di kerupuk ikan SPN kota jambi.

Keberhasilan suatu usaha diantaranya adalah peningkatan dalam akumulasi modal atau peningkatan modal, jumlah produksi, jumlah pelanggan, perluasan usaha, perluasan daerah pemasaran, perbaikan saran fisik dan pendapatan usaha. (Benedicta, 2003) Pendapatan perusahaan akan selalu menentukan tingkat kesuksesan financial dari suatau perusahaan tersebut, kesuksesan finansial sering bergantung kemampuan pemasaran. Finansial, operasional akuntansi dan fungsi bisnis lainnya tidak akan berarti jika tidak ada cukup permintaan akan produk dan jasa, sehingga perusahaan menghasilkan keuntungan. Harus ada pendapatan agar laba bisa di dapat. (Philip Kotler, 2009)

Karakteristik Pendapatan: 
Menurut skousen, dkk perusahaan merupakan dua kriteria pendapatan umum melalui daftar pengecekan atas empat faktor yang menjelaskan dua kreteria umum antara lain

1. Bukti yang meyakinkan adanya kesepakatan.

2. Pengiriman yang telah terjadi.

3. Harga atau biaya pemasok adalah tetap atau dapat di tentukan.

4. Tingkat ketertagihan yang tinggi. (Pratama Raharja, 2012)

\section{METODE}

Penelitian ini menggunakan model pendekatan penelitian kuantitatif dimana data sekunder dianalisis menggunakan metode analisis regresi berganda dengan penentuan informan penelitian total sampling. Pengumpulan data sebagai informasi untuk menjawaban perumusan masalah menggunakan metode wawancara, kuesioner dan dokumentasi.

\section{HASIL DAN PEMBAHASAN}

Tabel 2. Hasil Analisis Regresi Linear Berganda

\begin{tabular}{|l|r|r|r|r|r|}
\hline \multirow{2}{*}{ Model } & \multicolumn{2}{|c|}{$\begin{array}{c}\text { Unstandardized } \\
\text { Coefficients }\end{array}$} & $\begin{array}{l}\text { Standardized } \\
\text { Coefficients }\end{array}$ & \multirow{2}{*}{ S } & \\
\cline { 2 - 5 } & \multicolumn{1}{|c|}{ B } & Std. Error & \multicolumn{1}{c|}{ Beta } & \multicolumn{1}{c|}{ Sig. } \\
\hline 1 (Constant) & $3.981 \mathrm{E}-16$ & .114 & & .000 & 1.000 \\
Modal Kerja & .724 & .134 & .724 & 5.394 & .000 \\
Tenaga Kerja & .042 & .134 & .042 & .314 & .755 \\
\hline
\end{tabular}

a. Dependent Variable: Pendapatan

Sumber: Data diolah

Berdasarkan hasil perhitungan pada IBM SPSS statistics 22 maka diperoleh hasil linear berganda sebagai berikut:

$\mathrm{Y}=\mathrm{a}+\mathrm{b} 1 \mathrm{X} 1+\mathrm{b} 2 \mathrm{X} 2+\mathrm{e}$

$Y=3,981 E-16+0,724+0,042+0,114$

Dimana:

$\mathrm{Y}=$ Variabel terikat (pendapatan)

$\mathrm{X} 1=$ Variabel bebas satu (modal kerja)

$\mathrm{X} 2=$ Variabel bebas dua (tenaga kerja)

$\mathrm{a}=$ Nilai konstanta

b1 = Nilai koefisien regresi X1

b2 = Nilai koefisien regresi X2

$\mathrm{e}=$ Standar error

\section{Uji Parsial (Uji T)}

Uji parsial dilakukan untuk melihat secara individu variabel independent (X1) dan (X2) terhadap variabel dependent yang hasil perhitungan dapat dilihat pada gambar tabel berikut ini:
Tabel 3. Hasil Uji t (Parsial) Coefficients $^{\mathrm{a}}$

\begin{tabular}{|c|c|c|c|c|c|}
\hline \multirow[b]{2}{*}{ Model } & \multicolumn{2}{|c|}{$\begin{array}{l}\text { Unstandardized } \\
\text { Coefficients }\end{array}$} & \multirow{2}{*}{$\begin{array}{l}\text { Standardized } \\
\text { Coefficients } \\
\text { Beta }\end{array}$} & \multirow[b]{2}{*}{$\mathrm{T}$} & \multirow[b]{2}{*}{ Sig. } \\
\hline & $B$ & Std. Error & & & \\
\hline 1 (Constant) & $3.981 \mathrm{E}-16$ & .114 & & .000 & 1.000 \\
\hline Modal Kerja & .724 & .134 & .724 & 5.394 & .000 \\
\hline Tenaga Kerja & .042 & .134 & .042 & .314 & .755 \\
\hline
\end{tabular}

Sumber: Data diolah

Hasil perhitungan dalam tabel diatas menunjukan bahwa secara parsial (X1) Modal Kerja menghasilkan nilai signifikansi sebesar $0,000<0,05$ dengan $\mathrm{T}$ hitung $5.394>\mathrm{T}$ tabel 2.262 dengan demikian dapat disimpulkan bahwa secara parsial (X1) Modal Kerja berpengaruh secara positif dan signifikan terhadap variabel (Y) pendapatan kerupuk ikan SPN Kota Jambi. Hasil uji parsial untuk (X2) Tenaga kerja tidak terjadi pengaruh secara parsial terhadap (Y) pendapatan kerupuk ikan SPN kota Jambi karena nilai signifikan yang dihasilkan 0,755 >0,005 dan hasil T tabel 0,314< 2.262 .

\section{Uji Simultan (Uji F)}

Uji Simultan dilakukan untuk melihat apakah secara bersama-sama antara variabel (X1) modal kerja dan (X2) tenaga kerja berpengaruh terhadap (Y) dengan hasil dapat dilihat pada tabel berikut ini:

Tabel 4. Hasil Uji F (Simultan)

\begin{tabular}{|l|r|r|r|c|c|}
\hline Model & Sum of Squares & \multicolumn{1}{|c|}{ Df } & Mean Square & F & Sig. \\
\hline 1 Regression & 19.517 & 2 & 9.759 & 20.799 & $.000^{\mathrm{b}}$ \\
\multicolumn{1}{|c|}{ Residual } & 15.483 & 33 & .469 & & \\
\multicolumn{1}{|l|}{ Total } & 35.000 & 35 & & & \\
\hline
\end{tabular}
a. Dependent Variable: Pendapatan
b. Predictors: (Constant), Tenaga Kerja, Modal Kerja
Sumber: Data diolah

Berdasarkan table 4 uji simultan (uji F) diatas diketahui nilai signifikansi untuk pengaruh $\mathrm{X} 1$ dan $\mathrm{X} 2$ secara simultan terhadap Y adalah sebesar $0,000<0,05$ dan F hitung 20.799>4,10 F tabel. Sehingga dapat disimpulkan bahwa $\mathrm{H} 3$ diterima yang berarti terdapat pengaruh modal kerja (X1) dan tenaga kerja (X2) secara simultan terhadap pendapatan (Y).

\section{Uji Koefisien Determinasi (R2)}

Uji Koefisien Determinasi (R2) merupakan bagian dari variasi model regresi dimana uji ini melihat apakah model variabel independent bisa menjelaskan formasinya terhadap variabel dependent. Berikut ini penjelasannya: 
Tabel 5. Hasil Koefisien Determinasi (R2) Model Summary

\begin{tabular}{|l|l|r|r|r|}
\hline Model & R & R Square & $\begin{array}{c}\text { Adjusted R } \\
\text { Square }\end{array}$ & $\begin{array}{c}\text { Std. Error of } \\
\text { the Estimate }\end{array}$ \\
\hline 1 & $.747^{\mathrm{a}}$ & .558 & .531 & .68496473 \\
\hline
\end{tabular}

a. Predictors: (Constant), Tenaga Kerja, Modal Kerja

Sumber: Data diolah

Berdasarkan tabel 5 uji koefisien determinasi (R2) di atas dapat dilihat bahwa nilai koefisien determinasi (R2) $R$-Square adalah sebesar 0.558 hal ini menunjukkan bahwa variabel modal kerja dan tenaga kerja mampu menjelaskan pengaruh terhadap variabel pendapatan $55,8 \%$ dan $44,2 \%$ sisinya dapat dijelaskan oleh variabel lain yang tidak masuki dalam penelitian ini.

\section{SIMPULAN}

Berdasarkan pembahasan mengenai pengaruh modal, tenaga kerja terhadap pendapatan UMKM kerupuk Ikan SPN Kota Jambi di atas dapat disimpulkan sebagai berikut:

1. Variabel modal kerja berpengaruh positif dan signifikan terhadap pendapatan UMKM kerupuk ikan SPN Kota Jambi. Hal tersebut berdasarkan tabel 4.9 pengujian hipotesis $\mathrm{H} 1$, untuk pengaruh modal kerja (X1) terhadap (Y) adalah sebesar $0.000<0.05$ dan nilai $t$ hitung 5.394>2.262 t tabel. Sehingga dapat disimpulkan bahwa modal kerja (X1) berpengaruh positif dan signifikan terhadap pendapatan $(\mathrm{Y})$. Serta berdasarkan hasil penelitian dan perhitungan uji regresi linear berganda koefisien X1 ( modal kerja) bernilai positif sebesar 0.724 artinya menunjukkan bahwa setiap kenaikan modal kerja sebesar 1 satuan, sementara tenaga kerja dianggap konstan maka akan meningkatkan hasil pendapatan sebesar Rp. 0.724. jika semakin besar modal kerja maka semakin meningkat pula pendapatan.

2. Variabel tenaga kerja tidak berpengaruh secara signifikan terhadap pendapatan umkm kerupuk ikan SPN Kota Jambi. Hal tersebut berdasarkan tabel 4.8 pengujian hipotesis $\mathrm{H} 2$, diketahui nilai sig. untuk pengaruh tenaga kerja (X2) terhadap (Y) adalah sebesar 0,755>0.05 dan t hitung $0.314<2.262 \mathrm{t}$ tabel. Sehingga dapat disimpulkan bahwa tenaga kerja (X2) tidak berpengaruh secara signifikan terhadap pendapatan (Y). Serta berdasarkan hasil penelitian dan perhitungan uji regresi linear berganda koefisien X2 ( tenaga kerja) bernilai positif sebesar 0.042 artinya menunjukkan jika tenaga kerja mengalami peningkatan sebesar satu satuan, sementara modal kerja dianggap konstan maka akan menyebabkan kenaikan hasil pendapatan sebesar Rp. 0.042 .

3. Variabel modal kerja dan tenaga kerja berpengaruh positif dan signifikan terhadap pendapatan UMKM kerupuk ikan SPN Kota Jambi. Hal ini dibuktikan melalui pengujian uji $\mathrm{F}$ (simultan) diketahui nilai signifikansi untuk pengaruh $\mathrm{X} 1$ dan $\mathrm{X} 2$ secara simultan terhadap $\mathrm{Y}$ adalah sebesar $0,000<4,10$, sehingga dapat disimpulkan bahwa $\mathrm{H} 3$ diterima yang berarti terdapat pengaruh positif dan signifikan X1 dan X2 secara simultan terhadap Y.

\section{DAFTAR PUSTAKA}

Anindita Trinura Novitasari, "Pengaruh Modal Kerja, Keterampilan Tenaga Kerja, dan Inovasi Terhadap Pertumbuhan Usaha Kecil Batik di Kecamatan Tanjung Bumi Kabupaten Bangkalan" Vol 1, No 1. November 2017

Arininoer Maliha,"Pengaruh Modal, Tenaga Kerja Dan Bahan Baku Terhadap Tingkat Pendapatan Industri Kue". 2018

Benedicta prihatin dwi riyanti, Kewirausahaan Dari Sudut Pandang Psikologi Kepribadian, (Jakarta: Grasindo, 2003)

Dwi Nila Andriani, "Pengaruh modal, tenaga kerja, dan bahan baku terhadap hasil produksi (studi kasus pabrik sepatu pt. kharisma baru indonesia)." 152 | Equilibrium, Vol 5, No 2, juli 2017

Fitria Anggraeni, "Analisis Pengaruh Modal Kerja, Tenaga Kerja Dan Lama Usaha Terhadap Pendapatan Pengrajin Tas Di Kecamatan Krembangan Kota Surabaya." 2020.

Https://Www.Antaranews.Com/Berita/934192/PemprovJambi-Prioritaskan-Pembinaan-Umkm-Ke-

Jenjang-Lebih-Tinggi.

Komang Widya Nayaka, "Pengaruh Modal, Tenaga Kerja Dan Bahan Baku Terhadap Pendapatan Pengusaha Industri Sanggah Di Kecamatan Mengwi Bisnis Universitas Udayana, Bali, Indonesia, " 2018.

Kementerian Hukum dan Hak Asasi Manusia R.I UU No. 20 Tahun 2008 Tentang UMKM (Usaha Mikro Kecil Dan Menengah).

Mahardika Indra, Pengantar Mikro Ekonomi, (Yogyakarta: Quadrant, 2018). hlm 180

Meta Trisnawati, "Pengaruh modal kerja, tenaga kerja, jam kerja terhadap pendapatan nelayan tradisional di nagari koto taratak kecamatan sutera kabupaten pesisir selatan" 2013

Meilinda Khusniatus Sa'dah, "Pengaruh modal kerja, tenaga kerja, dan jam kerja terhadap pendapatan industri brem di kabupaten madiun" 2020

Nase Saepudin Zuhri,"'Sukses Membangun Wirausaha Prinsip, Strategi, Dan Kiat Melengkapi Kajian Perspektif Islam'. (Bandung: Fokusmedia, 2017).

Philip kotler dan Kevin lane keller, Manajemen Pemasaran, Jil I, (Jakarta: Erlangga, 2009).

Pratama Raharja, Pengantar Ilmu Ekonomi, (Mikroekonomi \& Makroekonomi), (Jakarta: FEUI).

Putu Danendra Putra, "Pengaruh modal dan tenaga kerja terhadap pendapatan dengan lama usaha 
Habriyanto, Bambang Kurniawan dan David Firmansyah, Pengaruh Modal dan Tenaga Kerja terhadap Pendapatan UMKM Kerupuk Ikan SPN Kota Jambi

sebagai variabel moderating". Vol .4, No.9 September 2015

Racmat. Syafee'i, Fikih Muamalah, (Bandung: CV.Pustaka Setia, 2001)

Rozalinda. "Ekonomi Islam, Teori dan Aplikasinya pada Aktivitas Ekonomi". (Jakarta: PT RajaGrafindo Persada juni 2014).

Suryana, Kewirausahaan Pedoman Praktis: Kiat Dan Proses Menuju Sukses. (Jakarta: Kencana, 2011).

Sonny Sumarsono, Ekonomi Sumber Daya Manusia Teori Dan Kebijakan Publik. (Jakarta: Graha ilmu, 2013).

Soemarso S.R, Akutansi Suatu Pengantar, Buku 2, (Jakarta: Salemba Empat, Cet 5, 2003). 